\title{
A rare aggravation of severe mucositis post chemotherapy in a child with acute lymphoblastic leukemia [version 1; peer
} review: 2 approved]

\author{
Adlette Inati ${ }^{1,2}$, Grace Akouri², Hussein A Abbas ${ }^{3}$ \\ ${ }^{1}$ School of Medicine, Lebanese American University, Byblos, Lebanon \\ 2Division of Pediatric Hematology Oncology, Rafic Hariri University Hospital, Beirut, Lebanon \\ ${ }^{3}$ Faculty of Medicine, American University of Beirut, Beirut, Lebanon
}

V1 First published: 24 Sep 2013, 2:196
https://doi.org/10.12688/f1000research.2-196.v1

Latest published: 24 Sep 2013, 2:196

https://doi.org/10.12688/f1000research.2-196.v1

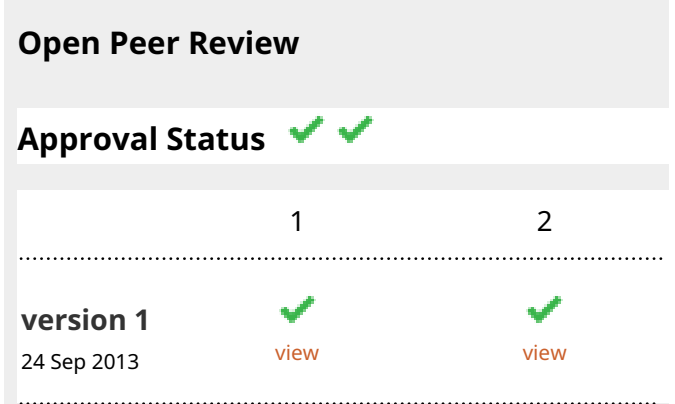

1. Bassem Razzouk, Peyton Manning Children's Hospital, Indianapolis, Indiana, USA

2. Jan Stary ID, University Hospital Motol, Prague, Czech Republic

Any reports and responses or comments on the article can be found at the end of the article. 
Corresponding author: Adlette Inati (adlette.inati@lau.edu.Ib)

Competing interests: No competing interests were disclosed.

Grant information: The author(s) declared that no grants were involved in supporting this work.

Copyright: $\odot 2013$ Inati A et al. This is an open access article distributed under the terms of the Creative Commons Attribution License, which permits unrestricted use, distribution, and reproduction in any medium, provided the original work is properly cited. Data associated with the article are available under the terms of the Creative Commons Zero "No rights reserved" data waiver (CC0 1.0 Public domain dedication).

How to cite this article: Inati $A$, Akouri $G$ and Abbas HA. A rare aggravation of severe mucositis post chemotherapy in a child with acute lymphoblastic leukemia [version 1; peer review: 2 approved] F1000Research 2013, 2:196

https://doi.org/10.12688/f1000research.2-196.v1

First published: 24 Sep 2013, 2:196 https://doi.org/10.12688/f1000research.2-196.v1 


\section{Case report}

We report a 5-year old female with average risk (AR1) pre-B acute lymphoblastic leukemia (ALL) who presented with severe oral mucosal pain and fever of $38.7^{\circ} \mathrm{C}$ on day 22 induction (EORTC Children's Leukemia Group protocol AR1 shown in Table 1).

On physical exam, the patient was sick-looking, lethargic and moderately pale. Her vital signs were: temperature $=38.7^{\circ} \mathrm{C}$, $\mathrm{HR}=120 / \mathrm{min}, \mathrm{RR}=24 / \mathrm{min}$ and $\mathrm{BP}=90 / 60 \mathrm{~mm} \mathrm{Hg}$. Her weight was $12.2 \mathrm{~kg}\left(<3^{\text {rd }} \%\right.$ for her age $)$ and her height was $110 \mathrm{~cm}(75 \%$ for her age). Her conjunctivae were mildly injected and her sclerae were non icteric. The oral cavity showed diffuse dental caries, severe mucosal erythema with whitish membranes and multiple necrotic and hemorrhagic lesions in the tongue, buccal mucosa and lower lip (Figure 1). She was unable to drink fluids or eat solid food (WHO mucositis stage IV) ${ }^{1}$. Her heart sounds were regular; a GII/VI systolic hemic murmur was heard all over the precordium. Lungs were clear and resonant. Abdomen was soft, non-tender with no hepatosplenomegaly or masses or ascites. There was no pathologic lymphadenopathy. Femoral pulses were symmetrical bilaterally and there was no peripheral edema. Neurologic exam, fundoscopy and skeletal exams were all normal. Laboratory tests upon admission showed severe neutropenia with moderate anemia and thrombocytopenia, increased prothrombin time (PT), partial thromboplastin time (PTT) and low fibrinogen (Table 2).

The patient was started on intravenous cefepime $(150 \mathrm{mg} / \mathrm{Kg} / \mathrm{d})$, vancomycin $(60 \mathrm{mg} / \mathrm{Kg} / \mathrm{d})$, fluconazole $(12 \mathrm{mg} / \mathrm{Kg} / \mathrm{d}$ on day 1 followed by $6 \mathrm{mgs} / \mathrm{Kg} / \mathrm{d}$ afterwards), topical mycostatin, $0.12 \%$ chlorhexidine mouthwash, adequate hydration and IV analgesia (perfelgan $15 \mathrm{mg} / \mathrm{kg}$ given q6 hours). She also received vitamin K, platelet transfusion and fresh frozen plasma. On hospitalization day 3 , the patient was still febrile with progressive mucositis and no oral intake. Micafungin $2.5 \mathrm{mg} / \mathrm{kg} /$ day was started and fluconazole was discontinued. Total parenteral nutrition (TPN) was also initiated and packed red blood cell and platelet transfusions were continued as needed. On day 4, admission cultures of the lesions of the tongue and buccal mucosa grew Candida albicans and coagulase-negative staphylococci while blood culture was negative.

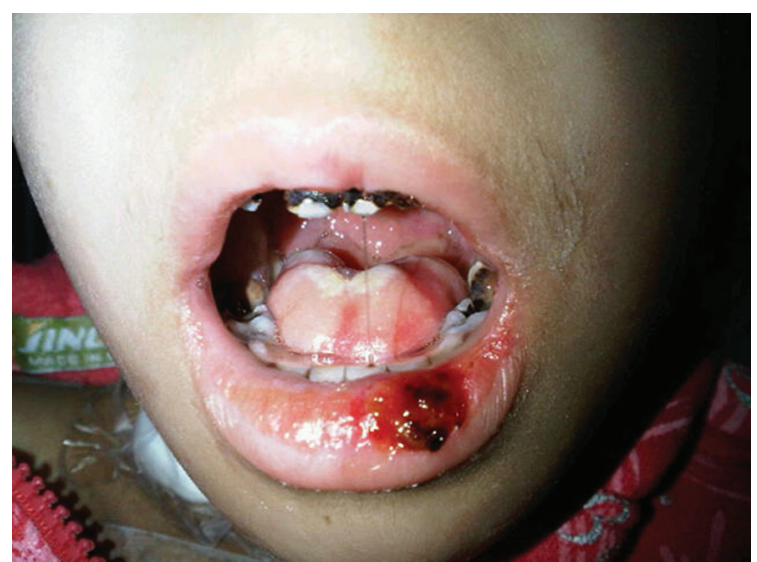

Figure 1. Patient's oral mucosa showing erythema and necrosis at time of presentation with oral mucosal pain and fever.

The patient was steadily but slowly improving when on hospitalization day 6 , she had an unexpected spontaneous shedding of the ventral part of her tongue (Figure 2). Pathological analysis of the detached tongue confirmed necrosis and bacterial and fungal cultures were negative. Her speech and feeding were further impeded by this trauma. The patient was continued on IV imipenem (100 mg/Kg/d), vancomycin (60 mg/Kg/d), amikacin $(20 \mathrm{mg} / \mathrm{Kg} / \mathrm{d})$ and fluconazole $(12 \mathrm{mg} / \mathrm{Kg} /$ day day 1 followed by $6 \mathrm{mgs} / \mathrm{Kg} /$ day afterwards) antimicrobials and TPN. A psychology consultation was offered to the parents and the patient. On hospitalization day 13 , her mucositis resolved and her oral food and fluid intake gradually recovered. Chemotherapy was initiated on hospitalization day 17 with no complications and the patient was discharged on day 22 in good condition. The family was instructed to adhere to the recommended daily oral care regimen consisting of topical mycostatin (100,000 unit/g applied BID), 0.12\% chlorhexidine mouthwash, gentle tooth brushing and adequate oral hydration.

Eight months after the incident, the patient recovered her ability to undergo oral maneuvers and her articulation steadily and

Table 1. EORTC Children's Leukemia Group Protocol AR1.

\begin{tabular}{lllll}
\hline Drugs & Dose & Route & Number of days/doses & Days \\
\hline Methotrexate & $12 \mathrm{mgs}$ & IT & 1 & 1 \\
\hline Prednisone & $60 \mathrm{mg} / \mathrm{m} 2 /$ day & PO & 28 & 1 to 28 \\
\hline Vincristine & $1.5 \mathrm{mg} / \mathrm{m} 2$ & IV & 4 & $8,15,22$ and 29 \\
\hline Daunorubicin & $30 \mathrm{mg} / \mathrm{m} 2$ & IV & 4 & $8,15,22$ and 29 \\
\hline L-Asparaginase & $10,000 \mathrm{U} / \mathrm{m} 2$ & IM & 8 & $12,15,18,22,25,29,32$ and 35 \\
\hline Methotrexate & $12 \mathrm{mg}$ & IT & 2 & 8,22 \\
Hydrocortisone & $15 \mathrm{mg}$ & IT & 2 & 8,22 \\
Cytosine Arabinoside & $30 \mathrm{mg}$ & IT & 2 & 8,22 \\
\hline
\end{tabular}




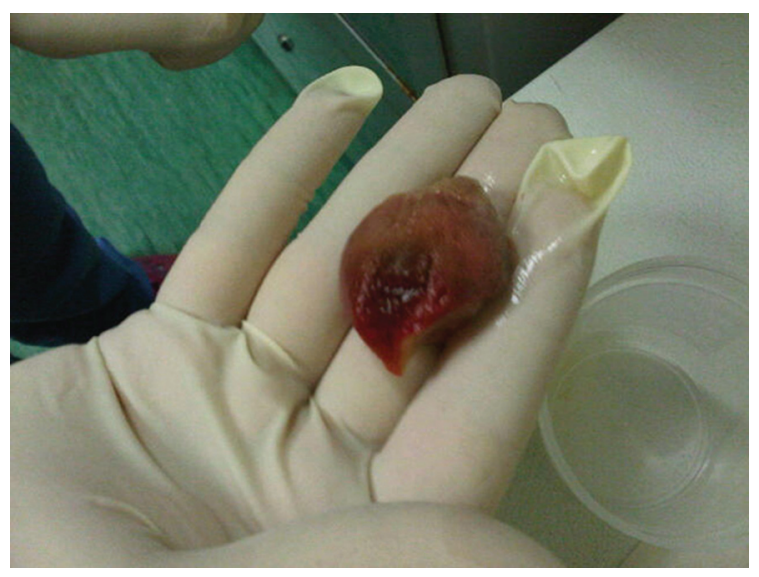

Figure 2. Shedding off the ventral part of the tongue.

progressively improved. Her tongue underwent compensatory hypertrophy (Figure 3). She continues, though, to have slightly unintelligible speech at times. Currently, the patient is in complete remission and receiving her maintenance chemotherapy.

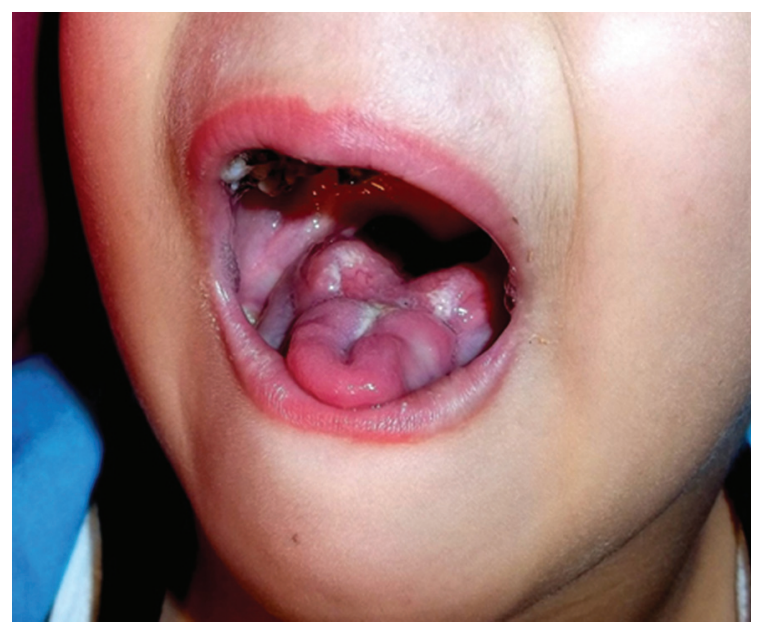

Figure 3. Tongue recovery 8 months after management.

\section{Discussion}

Leukemia and its treatment can adversely affect oral health. Leukemic cells are capable of infiltrating the gingiva and the deeper periodontal tissues resulting in local ulceration and infection. Mucosal cells are

Table 2. Laboratory results at presentation with fever and severe oral pain.

\begin{tabular}{|lll|}
\hline Lab test & Lab results & Normal values \\
\hline White blood cell count & $0.8 \times 10^{9} / \mathrm{L}$ & $4-11 \times 10^{9} / \mathrm{L}$ \\
\hline Hemoglobin & $7.8 \mathrm{~g} / \mathrm{dl}$ & $11.5-12.5 \mathrm{~g} / \mathrm{dL}$ \\
\hline Platelets & $28 \times 10^{9} / \mathrm{L}$ & $150-400 \times 10^{9} / \mathrm{L}$ \\
\hline Prothrombin time & $55.5 \mathrm{sec}$ & $9.8-12.7 \mathrm{sec}$ \\
\hline INR & 1.43 & $0.85-1.2$ \\
\hline Partial thromboplastin time & $54.2 \mathrm{sec}$ & $30-40 \mathrm{sec}$ \\
\hline Fibrinogen & $<0.5 \mathrm{~g} / \mathrm{L}$ & $1.8-3.5 \mathrm{~g} / \mathrm{L}$ \\
\hline D-DIMER & $158 \mathrm{\mu g} / \mathrm{L}$ & $63.8-246.4 \mathrm{\mu g} / \mathrm{L}$ \\
\hline Glucose & $80,87 \mathrm{mg} / \mathrm{dL}$ & $60-100 \mathrm{mg} / \mathrm{dL}$ \\
\hline Sodium & $129 \mathrm{mmol} / \mathrm{L}$ & $135-145 \mathrm{mmol} / \mathrm{L}$ \\
\hline Potassium & $3.58 \mathrm{mmol} / \mathrm{L}$ & $3.5-5.1 \mathrm{mmol} / \mathrm{L}$ \\
\hline Calcium & $7.92 \mathrm{mg} / \mathrm{dL}$ & $8.5-10.5 \mathrm{mg} / \mathrm{dL}$ \\
\hline Phosphorus & $1.45 \mathrm{mg} / \mathrm{dL}$ & $4-7 \mathrm{mg} / \mathrm{dL}$ \\
\hline Magnesium & $1.81 \mathrm{~m} / \mathrm{dL}$ & $1.71-2.29 \mathrm{mg} / \mathrm{dL}$ \\
\hline SGOT & $39.6 \mathrm{IU} / \mathrm{L}$ & $0-50 \mathrm{IU} / \mathrm{L}$ \\
\hline SGPT & $37.2 \mathrm{IU} / \mathrm{L}$ & $0-50 \mathrm{IU} / \mathrm{L}$ \\
\hline GGT & $30.2 \mathrm{IU} / \mathrm{L}$ & $7-64 \mathrm{IU} / \mathrm{L}$ \\
\hline Albumin/total protein & $26.85 \mathrm{~g} / \mathrm{L} / 43.3 \mathrm{~g} / \mathrm{L}$ & $38-54 \mathrm{~g} / \mathrm{L} / 60-80 \mathrm{~g} / \mathrm{L}$ \\
\hline INR & & \\
\hline
\end{tabular}

INR = International normalized ratio

SGOT = serum glutamic oxaloacetic transaminase

SGPT = serum glutamic-pyruvic transaminase

GGT = gamma-glutamyl transpeptidase 


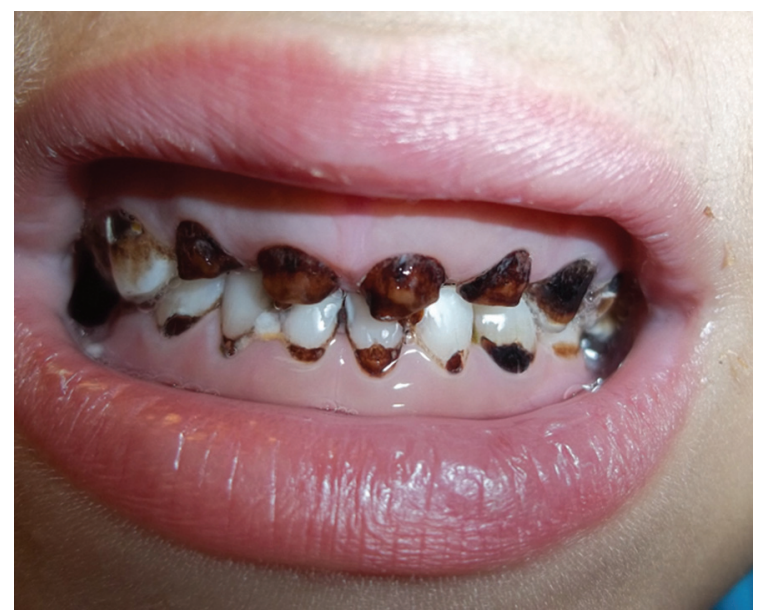

Figure 4. Dental caries at time of acute lymphoblastic leukemia diagnosis.

susceptible to chemotherapy due to their high mitotic rate 2 . Oral mucositis is the most frequent and debilitating complication of chemotherapy in children with cancer and can be associated with serious morbidities and increased risk of infection ${ }^{2-4}$.

The decreased salivary flow rate, salivary $\mathrm{pH}$ and total salivary antioxidant levels in leukemic children compared to controls can lead to further deterioration in their oral health status, gingival status and increased dental caries ${ }^{3,4}$. Our patient suffered from poor dental hygiene and severe dental caries when diagnosed with pre-B ALL (Figure 4). Oxidative stress per se may result in the onset of inflammatory oral pathologies. Saliva constitutes the first line of defense against free radical-mediated oxidative stress ${ }^{4}$. The biological manifestations of mucositis include a surge in lipopolysaccharides or endotoxins which activate macrophages and other mononuclear cells leading to production of nitric oxide, tumor necrosis factor (TNF), interleukin-6 (IL-6) and other cytokines ${ }^{5,6}$.

To our knowledge, this is the first report of very severe chemotherapy-induced mucositis leading to shedding of a part of the tongue. We hypothesize other factors in this patient may have led to this fulminant and unique clinical presentation. The poor oral hygiene and the advanced dental caries the patient had at the time of ALL diagnosis could have contributed to the flare up of chemotherapy induced mucositis and to the shedding of part of the tongue. This hypothesis conforms to the previously reported association of exacerbated oral mucositis with trauma from the teeth ${ }^{4}$. The degree of severity leading to tongue shedding in this patient was, however, remarkable. Notably, the tongue recovery and hypertrophic sublingual tissue seen in this patient 8 months after the incident are not unexpected and are a result of intrinsic tissue compensatory mechanisms which aided the patient in using her tongue for eating and speaking.
Children receiving chemotherapy should have critical and regular assessment of their oral mucosa before, during and after treatment. There are several oral assessment rating scales that can be used in cancer patients receiving chemotherapy such as the Oral Assessment Guide (OAG), Oral Mucositis Index (OMI) and Oral $\mathrm{Mu}-$ cositis Assessment Scale (OMAS) 7 . While OAG addresses the oral functionality and tissue keratinization, the OMAS and OMI focus on the degree of tissue abrogation ${ }^{7}$.

Careful oral management of children with cancer is critical and aims at preventing and treating mucositis and secondary infections as well as relieving pain and improving quality of life. An oral care protocol consisting of daily mouth rinsing with $0.12 \%$ chlorhexidine and tooth-brushing has been found to significantly decrease the incidence of ulcerative lesions, severity of oral mucositis and the related pain intensity compared to controls in pediatric cancer patients ${ }^{8}$. In infants and very young children who are unable to rinse, care-givers need to use the chlorhexidine or its equivalent as an oral swab.

\section{Conclusion}

This case represents a very severe chemotherapy-induced mucositis leading to a unique and previously unreported complication in a child with leukemia. It illustrates the fact that critical and regular assessment of the oral mucosa and proper dental care and oral hygiene are mandatory in all pediatric patients receiving chemotherapy. Physicians caring for children with cancer need to be aware of this rare complication and educate families about the benefits and modalities of optimal oral hygiene and the need to immediately report to their child's health provider for mouth pain and or lesions. Additionally, vigilant treatment of mucositis needs to be instituted without delay in this high risk patient population. Such a preventive and therapeutic approach may prevent life threatening oral and systemic complications, promote mucosal healing and potentiate the hypertrophic compensatory action of linguinal cells thereby ensuring rapid and complete recovery.

\section{Consent}

Written informed consent for publication of clinical details and clinical images was obtained from the patient's legal guardian.

\section{Author contributions}

Dr. Inati and Dr. Akouri diagnosed, followed up the patient and reviewed the manuscript. Dr. Abbas followed up on the case and wrote the manuscript.

\section{Competing interests}

No competing interests were disclosed.

\section{Grant information}

The author(s) declared that no grants were involved in supporting this work. 
1. WHO: Handbook for reporting results of cancer treatment. Geneva, Switzerland: World Health Organization. 1979; 45 Reference Source

2. Schwab M, Zanger UM, Marx C, et al.: Role of genetic and nongenetic factors for fluorouracil treatment-related severe toxicity: a prospective clinical trial by the German 5-FU Toxicity Study Group. J Clin Oncol. 2008; 26(13): 2131-2138. PubMed Abstract | Publisher Full Text

3. Hegde AM, Joshi S, Rai K, et al.: Evaluation of oral hygiene status, salivary characteristics and dental caries experience in acute lymphoblastic leukemic (ALL) children. J Clin Pediatr Dent. 2011; 35(3): 319-323.

PubMed Abstract

4. Raber-Durlacher JE, Elad S, Barasch A: Oral mucositis. Oral Oncol. 2010; 46(6): 452-456.

PubMed Abstract | Publisher Full Text
5. Gifford GE, Lohmann-Matthes ML: Gamma interferon priming of mouse and human macrophages for induction of tumor necrosis factor production by bacterial lipopolysaccharide. J Natl Cancer Inst. 1987; 78(1): 121-124. PubMed Abstract

6. Sonis ST: Mucositis as a biological process: a new hypothesis for the development of chemotherapy-induced stomatotoxicity. Oral Oncol. 1998 34(1): 39-43.

PubMed Abstract | Publisher Full Text

7. Eilers J, Million R: Prevention and management of oral mucositis in patients with cancer. Semin Oncol Nurs. 2007; 23(3): 201-212.

PubMed Abstract | Publisher Full Text

8. Cheng KK, Molassiotis A, Chang AM, et al.: Evaluation of an oral care protocol intervention in the prevention of chemotherapy-induced oral mucositis in paediatric cancer patients. Eur J Cancer. 2001; 37(16): 2056-2063.

PubMed Abstract | Publisher Full Text 


\title{
Open Peer Review
}

\section{Current Peer Review Status:}

\section{Version 1}

Reviewer Report 25 September 2013

https://doi.org/10.5256/f1000research.2355.r1892

(c) 2013 Stary J. This is an open access peer review report distributed under the terms of the Creative Commons Attribution License, which permits unrestricted use, distribution, and reproduction in any medium, provided the original work is properly cited.

\begin{abstract}
Jan Stary
Department of Pediatric Hematology and Oncology, University Hospital Motol, Prague, Czech Republic

The authors present the unusually severe complication of mucositis developed during the induction treatment of acute lymphoblastic leukemia. They stress the need for education of family and patients about the importance of oral hygiene during the intensive chemotherapy. The paper is well written and documented.

Competing Interests: No competing interests were disclosed.

\section{I confirm that I have read this submission and believe that I have an appropriate level of expertise to confirm that it is of an acceptable scientific standard.}

Reviewer Report 24 September 2013

https://doi.org/10.5256/f1000research.2355.r1889

(c) 2013 Razzouk B. This is an open access peer review report distributed under the terms of the Creative Commons Attribution License, which permits unrestricted use, distribution, and reproduction in any medium, provided the original work is properly cited.

\section{Bassem Razzouk}

Children's Center for Cancer and Blood Diseases, Peyton Manning Children's Hospital, Indianapolis, Indiana, USA

This is a very well written case report about severe oral mucositis in a patient with ALL receiving induction therapy. The existing severe dental caries present at the diagnosis of ALL most likely contributed to the severity of the condition, which was managed appropriately and aggressively. 
Competing Interests: No competing interests were disclosed.

I confirm that I have read this submission and believe that I have an appropriate level of expertise to confirm that it is of an acceptable scientific standard.

The benefits of publishing with F1000Research:

- Your article is published within days, with no editorial bias

- You can publish traditional articles, null/negative results, case reports, data notes and more

- The peer review process is transparent and collaborative

- Your article is indexed in PubMed after passing peer review

- Dedicated customer support at every stage

For pre-submission enquiries, contact research@f1000.com 